\title{
Cultures in Dialogue. Institutional and Individual Challenges for EU Institutions and EU Citizens from the Perspective of Legal Linguistics ${ }^{1}$
}

\begin{abstract}
In the European Union, numerous cultures have entered into dialogue. Currently, there are 23 official languages (EU languages) and therefore 506 possible language combinations for translation. This makes demands on the EU institutions and on EU citizens as well. Linguistic divergence makes legal certainty a rather shaky matter. There are also divergences from the EU linguistic regime regarding the official and the working languages. For reasons of efficiency, the institutions of the Union communicate internally in merely a small number of working languages, for the most part without any basis for this in the Rules of Procedure. The Court of Justice of the European Union traditionally uses French. All documents are translated from the language of the case into the working language. Although the decision, formulated in French, is re-translated into the language of the case, this translated version is classified as the original version and not as a translation. This is of importance for the status of authenticity because the decision only has full legal effect in the language of the case.

Traditional language models favour a reduction of the EU languages. Their representatives argue either with regard to the practice of the use of three languages in the EU institutions, or they advocate English as a global language, or they call for neutral languages. In contrast, the European Reference Language Model, which is developed along the lines of legal linguistics, suggests a concept of reference and native languages. It would lead to a reduction in the translation load in Brussels and Luxembourg. But first and foremost, it would be able to improve the linguistic quality of legal documents (e.g., directives, regulations) and therefore also their application to legal practice (e.g. legal certainty, comprehensibility of legal texts). At the same time, the model respects the dignity of each EU Member State in the form of its language.
\end{abstract}

\section{Introduction}

The European Union strives to preserve the wealth of cultural and linguistic diversity. The Charter of Fundamental Rights of the European Union anchors the respect for linguistic diversity and the prohibition of any kind of discrimination for reasons of language (see Articles 21(1), 22). Furthermore, the equal treatment of all EU languages is here given legal effect. As part of culture and national identity, they fall under the protection and the respect of the Union. This also applies to the numerous regional and minority languages. The equality of the EU Member States is reflected in the equal treatment of their languages. Linguistic diversity is considered a constitutive feature of European identity. But what is the effect of multilingualism in the EU law? How are the 23 languages which are considered to be equally authentic (Article 358 TFEU, ex-Article 314 TEC) actually handled in communication?

It is not only in internal communication at the institutional level that all official languages are to be used equally as working languages, but also in external communication, any important documents are to be published in all the official languages. Every EU citizen is to have the same

1 The language of this contribution has been checked by Dr Kerstin Kazzazi of the University of Eichstätt-Ingolstadt to whom the author expresses her warmest thanks.

\footnotetext{
* Karin Luttermann

Katholische Universität Eichstätt-Ingolstadt

Deutsche Sprachwissenschaft und Europastudien, SLF

Universitätsallee 1

D-85072 Eichstätt

karin.luttermann@ku-eichstaett.de
} 
opportunities of communication with the EU institutions (e.g., European Parliament, Court of Justice of the European Union). He or she must be able to address an institution in his or her own official language and also to receive an answer in this same language, for the simple reason that the protection of the rights and duties of the EU citizen is of particular importance in the domain of language (Articles 2 and 3 of Council Regulation No 1).

In reality, however, the EU institutions have stopped treating all languages the same, for reasons of practicability, and without any noticeable legal foundations, by using only certain languages on their own authority. Although Article 1 of Council Regulation No 1 places the official languages and the working languages on a par through the use of the coordinating conjunction and, a grey area has developed in the parallel use of official and non-official languages. The option that the institutions may regulate the EU language question of their own accord in the Rules of Procedure has not been implemented in practice yet (Article 6 of Council Regulation No 1). The contradictions in the institutional handling of multilingualism demand a reform.

The European Union needs a practicable language regulation for communication with EU citizens on the ground of legal certainty. This includes linguistic certainty about the meaning of legal words and legal texts, too. Linguistics (as well as jurisprudence) has long neglected this problem area, although questions of communication in intercultural language regions constitute genuinely linguistic questions. The immediate relevance for research is clearly visible. In order to make the Union fit for the future, a solution of the language question is necessary and of top priority. What conceptual developments are there? The present contribution suggests a solution to the language question from a legal-linguistic point of view in the form of the European Reference Language Model (section 8). The model opens up a wide academic and practical professional field within the largest economic area (single market) in the world, in particular for our discipline and its students.

The European Reference Language Model forms the central topic of this paper. Prior to its presentation, for a better understanding of its main categories and ideas, we will first treat the historical development of multilingualism in the European Union (section 3), second language use in the EU institutions with special reference to the Court of Justice of the European Union (sections 4 and 5), third linguistic divergence to the detriment of legal certainty (section 6), and fourth some conventional models developed by linguists (section 7). As a basis, the contribution sets in with different types of the EU linguistic regime.

\section{Four types of the EU linguistic regime}

In the European Union, the main languages of the EU Member States are used in multilingual communication. They may serve as treaty languages, official languages, working languages or languages of the case. The Founding Treaties, the Consolidated Versions and the Accession Treaties are written in the treaty languages. Article 358 TFEU (ex-Article 314 TEC) in conjunction with Article 55 TEU says that the wording of every language version is equally authentic in the EU Member States. The principle of equal authenticity rests on the presumption that the terms of a treaty have the same meaning in each authentic text. Each of the language versions constitutes the single original. All treaty languages also function as official languages (Article 1 of Council Regulation No 1). In the EU institutions, they are used in external communication. They are employed for official publications of general application. Working languages are languages in which the EU institutions communicate internally. In contrast to what is actually practiced, the working languages should correspond to the official languages, or there should be additional regulations in the Rules of Procedure (see above section 1). All languages in which court proceedings may be conducted at the Court of Justice of the European Union are called languages of the case (see below section 5). They are fixed in the Court's Rules of Procedure and not, like the other three language categories, as primary law in the Founding Treaties of the European Union, or as secondary law in the Council Regulation No 1. These four types are significant in particular for the development of language models as an alternative to the EU linguistic regime (see below sections 7 and 8). 


\section{Steps of EU language development}

Right from the start, the language question was a highly controversial topic for the economically and politically unified Europe. Among the founding nations (Belgium, Germany, France, Italy, Luxembourg, the Netherlands) it was mainly between Germany and France that linguistic leadership was disputed. In the Treaty establishing the European Coal and Steel Community, French prevailed. Eventually, an interim committee implemented a pluralistic form of language use and refuted France's monolingual aspirations. The Treaties establishing the European Economic Community and the European Atomic Energy Community made equal language use mandatory. Drawn up in a single original in the official languages of the EU Member States, all texts are equally authentic according to Article 358 TFEU (ex-Article 314 TEC). On the basis of Article 342 TFEU (ex-Article 290 TEC), the Council passed the Regulation No 1, determining the languages to be used by the European Economic Community on the $15^{\text {th }}$ of April 1958. Initially, it declared French, German, Dutch and Italian to be official and working languages at Community level.

The Consolidated Versions confirmed the linguistic regime of the European Economic and Atomic Energy Community for the European Community and the European Union. During the course of the years, the language regulation was adapted to the rising number of the acceding EU Member States and therefore of EU languages, without, however, any essential change happening. Since the accession of Bulgaria and Romania in the year 2007, the European Union has 27 member states, three alphabets (Latin, Greek, Cyrillic) and 506 possible language combinations for the translation among 23 official languages (in historical order): ${ }^{2}$ French, German, Dutch, Italian, Danish, English, Greek, Portuguese, Spanish, Swedish, Finnish, Lithuanian, Latvian, Estonian, Hungarian, Polish, Slovenian, Slovak, Czech, Maltese, Irish, Romanian and Bulgarian. In 2006, Basque, Galician and Catalan were accorded a special position.

\section{The use of EU languages in EU institutions}

The criterion of the equality of all EU languages has not been repealed in the seven rounds of enlargement. After roughly 50 years, the number of the official languages has increased to nearly six times the number of the initial four between 1957 and 2007, and the number of language combinations from 12 to 506. The neglect of the language question is regarded as a "foundation secret of the Community". ${ }^{3}$ Officially, the Council intends to maintain institutional multilingualism, and the basic documents insist on plurality (see above sections 2 and 3). There shall be one voice, but this is to be heard in 23 EU languages. However, the picture is deceptive. The European Union, it is true, does not question the principle of equal treatment of all official and working languages. However, in actual linguistic practice, a restriction partly of the official languages and the working languages in particular is the most natural thing in the world. ${ }^{4}$ The linguistic unification tendencies with regard to working languages in EU institutions were conceded even by the former Romanian Commissioner for Multilingualism Leonard Orban. According to him, linguistic diversity does not constitute an obstacle internally or in external relations. At the working level, such a multitude of voices would, however, overtax the resources of the EU institutions. ${ }^{5}$

Within the European Commission (Brussels), which makes suggestions for legal regulations to the Parliament and the Council, English and French and, to a lesser extent, German are the working languages, although Article 18 paragraph 1 and 6 Rules of Procedure of EC fixes the equal treatment of the languages. In the European Parliament (Strasbourg, Brussels), which represents the EU citizens, linguistic plurality is disregarded in particular in preparatory work and informal meetings, and a reduced number of working languages is used, with a preference for English (see

2 See K. Luttermann (2007: 52-56).

3 Ehlich/Redder (2008: 14).

4 See van Els (2006: 18).

5 EU-News No 32 of 27.9.2007, p. 1. 
Article 138 Rules of Procedure of EP). The reasons are organisational limits, such as necessary translations of amendments not being available yet, or insufficient availability of interpreters. ${ }^{6}$ Alain Lamassoure, a former French minister of European Affairs, did not succeed in officially reducing the working languages in the European Parliament to five.

In the Council of the European Union (Brussels), which, together with the Parliament, passes the EU laws and functions as the Union legislator, the language situation is comparable to that in the Commission. The decisions of the Council of Ministers are prepared by a committee consisting of the standing representatives of the EU Member States. The work is carried out exclusively in English, French and German. ${ }^{7}$ On grounds of urgency, the Council is even allowed to deviate from the use of the 23 languages unanimously (see Article 14 paragraph 1 Rules of Procedure of Council). The European Court of Auditors (Luxembourg) examines whether the public resources are managed properly to the advantage of the EU citizens. The internal languages are English and French. The annual and special reports are published externally in all EU languages (see Article 24 paragraph 1 Rules of Procedure of ECA). This takes us to the Court of Justice of the European Union. This institution shapes EU law and sets the yardstick for the interpretation of legal texts. Are there any languages which predominate in internal communication?

\section{Handling of multilingualism at the Court of Justice of the European Union}

\subsection{Proceedings}

The Court of Justice of the European Union (Luxembourg) is the highest court in matters of European Union law. The treaties provide it with the power of consistent application of EU law across the EU Member States. Article 342 TFEU (ex-Article 290 TEC) and Article 7 of Council Regulation No 1 say that language use at the Court is to be regulated separately in the Rules of Procedure. The Court of Justice has done this in the Articles 29 to 31 Rules of Procedure of ECJ. Accordingly, the language of a case shall be every official language (Article 29(1) Rules of Procedure of ECJ). This is to ensure that an EU citizen may communicate at the Court in his or her native language, linguistic diversity being maintained and discrimination being prevented (see above section 1). The applicant has the privilege of language choice (Article 29(2) Rules of Procedure of ECJ). The decision drawn up in the language of the case is authentic (Article 31 Rules of Procedure of ECJ). It has to be translated by the Court's own language service into all EU languages and to be published in the European Court reports (Article 30(2) Rules of Procedure of ECJ).

Looking at legal reality, i.e., the actual implementation of the language regulation at the Court of Justice of the European Union, differences become immediately obvious. There can be no talk of the equal handling of all the EU languages in the face of the preference for French. The French language is "the almost exclusive working language." ded into the Court's Rules of Procedure. There is neither a legal basis for French as the working language, nor a regulation prescribing the special status of one specific language. It simply says on the home page of the Court: "The Judges deliberate, without interpreters, in a common language which, traditionally, is French." "They exclusively, and regardless of their linguistic competence, consult in French, in order to maintain the character of non-publicity without interpreters. In addition, they write the court decisions in French. If the language of the case is not identical with this, the decision has to be translated. For it is only authentic in the language of the case. The

\footnotetext{
6 See Gahler (2007: 62-63).

7 See Lölke (2007: 67-69).

8 Ammon (2001: 2).

9 At http://curia.europa.eu/jcms/jcms/Jo2_7024/ (23.1.2011). This is an update of http://curia.europa.eu/de/instit/services/traduction/regime.htm (5.4.2008) which has been moved as a result of the restructuring of the Curia site. See K. Luttermann (2007: 67): "The Court must use a common language in its consultations. This language is traditionally French. All documents sent to the Court (...) in the language of the case are therefore translated into French, in order to provide a working basis."
} 
original version of the decision is thus usually written in French and not - as it may seem - in the language of the case (e.g., Polish, Swedish). Even at the point of announcement, a flawed language version may thus exist; this applies all the more as the French translation bureau has to work under great time pressure, in order to be able to make the decision available to the citizens of all EU Member States simultaneously. Errors may be reiterated in the texts in the other official languages and therefore endanger the legal certainty of the EU citizens.

Since 2003, it has also been common practice, for reasons of economy, not to translate every decision into all official languages any more. The versions in the language of the case and French are sufficient, if in the view of the Court, translations into other languages are of no importance. ${ }^{10}$ They are also not included in the European Court reports. In this way Article 30(2) Rules of Procedure of ECJ, which orders that publications of the Court shall be issued in the languages referred to in Article 1 of the Council Regulation No 1, is circumvented. This is a questionable procedure. Furthermore, the legal reality at the Court of Justice of the European Union diverges from the legal foundations in that the Advocates General have agreed to write their opinions primarily in the working language for the benefit of the Judges and their deliberations, with the aim of saving efforts in translations, time and money. This again leads to a preference for French.

\subsection{Methods for interpreting the European Union law}

According to Article 19 paragraph 1 TEU (ex-Article 220 TEC), the Court of Justice of the European Union shall ensure that in the interpretation and application of the Treaties the law is observed. It is tasked with interpreting EU law and ensuring its equal application across all EU Member States. The mission is formulated in all treaty languages. The Judges thus have to deal with every language version. The principle of equal authenticity obliges them to compare all the official languages of the authentic texts of a treaty and reconcile any discrepancies in meaning that might occur. Methdologically, the Court of Justice provides the grammatical, historical, systematic and teleological interpretation. This involves a legal language comparison. ${ }^{11}$ The point of departure is the linguistic comparison. The first step is the determination of the meaning of each language version. Then divergences in the meaning are highlighted. In a third step, finally, the Court of Justice of the European Union has to decide between the diverging meanings. This is the point at which legal comparison comes in. In the case of linguistic divergence, interpretation is to be systematic and - authoritatively - teleological, i.e., according to the sense and purpose of the legal norm and according to context, no matter how many languages are involved (see below section 6). The Court of Justice has made a landmark decision in the Case Van der Vecht: ${ }^{12}$ The need for uniform interpretation of Community regulations makes it impossible in case of doubt about the wording of a provision to be considered in isolation and requires that it should be interpreted and applied in the light of the versions existing in the other official languages. As the languages are equally authentic, they are of equal weight in the interpretation process.

\section{Linguistic divergence through translations in European Union law}

\subsection{Legal certainty}

Multilingualism has the advantage of making many provisons of the Treaties and of secondary legislation (e.g., regulations, directives and decisions) available to every EU citizen. However, the disadvantages should not be overlooked. The Europeanization of national laws creates "additional problems of language and comprehension." ${ }^{13}$ In addition, because of the equal authenticity of the language versions, there is "in fact a high probability of divergences ${ }^{14}$. For there are differences

10 See Levits (2007: 46).

11 See C. Luttermann (1999).

12 ECJ, decision of 5.12.1967, ECR 1967.

13 Schubarth (2001: 55).

14 Christensen/Müller (2004: 11). 
not only in the languages and the structures of a text, but also in the respective legal cultures. Quite rightly, there is the warning that legal certainty might fall victim to the multiplication of perspectives. But certainty, it is said, becomes the less possible, the more languages of equal status are in competition regarding the 'correct' interpretation of the law. The existence of many equally authentic languages, thus the line of argumentation, leads to the danger of providing the judges with too great a discretion for decision-making. ${ }^{15}$ This is not only problematical with regard to the division of power, but also with regard to the demand for legal certainty for the individual citizen. Rainer Wimmer (2009: 238) counters these objections, arguing that the Court of Justice of the European Union cannot have enough languages to grasp the facts in question. However, he overlooks completely that differences between the vocabularies of various language systems in the final instance are not decided through language, but by way of juridical arguments. In interpreting the treaty, the Court is generally concerned with its broad purposes, rather than with narrow wording. Language can thus not be decisive in resolving a conflict of meaning. The result of interpreting Treaties and texts of secondary legislation in a language is, with regard to European legal integration, the determination of a uniform meaning of EU terminology. ${ }^{16}$

What is more, the current legal situation shifts linguistic divergence onto the EU citizen. In case of doubt, he or she has to make sure, whether, and if so, what differences there are between the versions existing in the other official languages. He or she can no longer - as is usual in national law - consider in isolation the wording of a provision phrased in his or her native language and count exclusively on this. A comparison with all other versions is always necessary. The law is thus made available to the EU citizen in his or her own language and this version is equally authentic to all others. However, he or she cannot be sure, "whether in the case of language problems his right to his language can always be realised." ${ }^{17}$ First of all, however, EU citizens have to be made aware of this problem. It does not seem to be widely known yet. All in all, the numerous translations in European Union law involve linguistic divergence at the expense of legal certainty to the detriment of the EU citizens.

\subsection{Example and linguistic comment}

The Court of Justice of the European Union has to ensure that EU law is observed in the interpretation and application of the Treaties. In the case of divergence between the language versions of a Community instrument, the provision in question must be interpreted by reference to the purpose and general scheme of the rules of which it forms a part. The elimination of linguistic discrepancies by way of interpretation may in certain circumstances run counter to the concern for legal certainty, inasmuch as one or more of the texts involved may have to be interpreted in a manner at variance with the natural und usual meaning of the words. ${ }^{18}$ In consequence, the individual citizen cannot rely on the version available in a single EU language. An example is the Case Koschniske: ${ }^{19}$ The female German citizen Koschniske receives a Netherlands familiy allowance for her under-age children. She brings an action against the decision by the competent Netherlands institution to suspend payment of that allowance because her husband works in Germany and draws dependent child benefits there. However, in the Dutch text, there is only mention of the female spouse (echtgenote) and not of the male spouse (echtgenoot). The claim to benefits only expires if the wife has a job and gets family allowance from another EU Member State. This does not apply here. The Court has to clarify whether echtgenote (wife) must also be understood to mean a married man. To this end, all language versions have to be considered as being equally authentic. A comparison reveals that, in all the other versions, a word has been used which equally includes male and female employees: in Danish (cegtefaelle), German (Ehegatte), English (spou-

15 See Baumann (1999: 21); Christensen/Sokolowski (2004: 114).

16 See Šarčević (1997: 229-269) on terminological problems.

17 Berteloot (2004: 187).

18 ECJ, decision of 3.3.1977, ECR 1977, margin no. 11 - North Kerry Milk Products Ltd.

19 ECJ, decision of 12.7.1979, ECR 1979. 
se), French (conjoint) and Italian (coniuge). Only the Dutch text has echtgenote for female spouse. Considered by itself, it gives the impression that the term used refers exclusively to a person of the female sex. However, the Court is of the opinion, in a joint European interest, that the male spouse (husband) is also included. For the purpose of the regulation is to avoid the overlapping of family allowances for the same children and to treat male and female employees equally with regard to social security.

From a linguistic point of view, this decision seems untenable. For the grammatical system of an individual language is completely ignored. The Court of Justice of the European Union takes the Dutch feminine form echtgenote (female spouse), against the norm of the Dutch language, to be a generic term for male and female spouse. This twists the Dutch language. This would be as if the German text had Gattin. Such a term cannot be taken to refer to a male person. Echtgenoot and echtgenote stand in participatory opposition. This means: The masculine unmarked term echtgenoot as a generic term can include man and woman, but not the other way round. The feminine form echtgenote is the marked form. The generic masculine stands for the use of masculine personal terms for reference to both sexes. It may be used to also include women. The fact that the Court of Justice interprets the Dutch version, against wording and rules of language use, as referring to male and female spouse, endangers legal certainty, because the plaintiff cannot rely on the unambiguous wording in the language version referred to by her. Thereby, the Court of Justice of the European Union places itself in contradiction to its own decision that none of the national texts is allowed to be violated by an interpretation. Whether there are any other comparable cases could be shown by an empirical analysis of the case-law of the Court. European Union law can, however, only be comprehensible for its citizens, if it respects the individual languages.

Legal considerations in this context relate either to some core languages at the working levels, ${ }^{20}$ or to restoring Latin as the lingua franca of Europe, ${ }^{21}$ or to using global English as the main tool of communication in the European Union, ${ }^{22}$ in order to save capacities in translation and work load and to improve the legal position of the EU citizens. What have linguists contributed to modifying language arrangements in the EU institutions?

\section{Approaches by linguistics}

The examination of linguistic studies reveals the following: Ideas developed by linguistics for modifying the EU linguistic regime (see above section 2) essentially all go in the direction of drastically reducing the plurality of official languages; this also applies to the legal experts, with a different reasoning, however (see above section 6.2). If multilingualism is not to be maintained in the EU institutions, which models would be conceivable?, asks Heinrich Kelz (2002: 7). He thus opens the view for the premises, under which linguists have largely developed language models. Although they are united by the aim of expressing European Union law in less than the currently 23 languages, they proceed from different starting points. There is a variety of 'one-language' models and reduced multilingual models. ${ }^{23}$ The 'one-language' models propagate one lingua franca for the communication in the EU institutions and with the EU citizens, accepting the abandonment of the multilingual idea, that was codified by the European politicians in particular in the Treaty on European Union (see above section 3). The basic idea was, with regard to the harmonization of the European Union, that a common European language is needed. There are several options for this.

One option is Latin, which is the root of many European languages and has influenced many national legal orders; another is Esperanto as the most successful and most widespread planned

20 See Lohse (2004: 106); Schübel-Pfister (2004: 513).

21 See Sturm (2002: 319-320). Differently Mattila (2008: 253, 263-264).

22 See Kirchhoff (2002: 220).

23 See Ammon (2006); Chaudenson (2001); K. Luttermann (2008: 220-221); Wu (2005). Concepts that are more elaborate - e.g., on the production of multilingual texts or on linguistic comparison - are lacking. 
language in the world, which - like Latin - is also neutral, i.e., not spoken by any EU citizens as a mother tongue. The third option is French, due to its having the status of the language of diplomacy and the main EU institutions being located in francophone areas. The fourth option is English, that is, the language of the second-largest native speaker group in the European Union (see below section 8.4). For this option, the situation outside of Europe, i.e., the spread of English over all continents, is adduced; in addition it is argued that English is already the foreign language taught most widely. In the discussion in Germany in particular this option is often presented as the truly economic and only sensible one that all developments are tending towards anyway. ${ }^{24}$

On the other hand, there are the reduced multilingual models which see the future of Europe in an alternative scenario, i.e., a scenario without monolingual thinking and acting and without a neutral, de-nationalized language. They pursue the reinforcement of certain EU languages, while at the same time preventing English from becoming the lingua franca in the European Union. From the pool of the official languages, they give preference in particular to English, French and German - partly also in combination with Dutch, Italian or Spanish. The line of arguments takes into account the Roman Treaty languages, i.e., those languages in which the Treaty establishing the European Economic Community and the Treaty establishing the European Atomic Energy Community were first written (Dutch, French, German, Italian), but also geographical extension (German, English, Spanish), numerical and economic strength (German, English). In particular, however, emphasis is placed on the fact that in practice, work is already carried out efficiently in these languages; this applies not only to the main EU institutions (see above section 4), but also to the independent special EU institutions, namely the European Central Bank in Frankfurt/Main (English), the European Patent Office in Munich (English, French, German) and finally the Office for Harmonization in the Internal Market in Alicante (English, French, German, Italian, Spanish). These models form the background for comparison with the European Reference Language Model, which is oriented mainly towards legal certainty and linguistic democracy (see below section 8.2).

\section{Suggested solution: European Reference Language Model}

\subsection{Point of departure}

Isolde Burr and Tito Gallas (2004: 198) say that European Union law has to be communicated to the EU citizen in a form that it is comprehensible to him or her in the national language (the language spoken by the majority of the population); they are of the opinion that a mere translation without the claim to equal authenticity of all official languages cannot meet this demand. By implication this means: the demand is met if this claim is taken into consideration. Language thereby becomes the crucial point for the effect of European Union law. ${ }^{25}$ The crux of the matter is what is understood by equal authenticity of languages (Article 358 TFEU, ex-Article 314 TEC). This is where legal linguistics comes in. The term equally authentic needs to be filled in a legal-linguistic way, so that EU law has a common language for maintaining legal certainty, while at the same time respecting all official languages. It is only in this way that it can be comprehensible for its citizens (see above section 6.2 and below sections 8.2 and 8.4). This is what Michael Clyne (1995: 16) is driving at, when he says: „The challenge of the European Union is to promote diversity within a structure that is very centralist." On the one hand, linguistic diversity is to be maintained, on the other, a unified Europe is to be created. This is the background from which the following guiding questions emerge: In what way can multilingual legal communication in the EU institutions be made simple and legally certain, without abandoning the claim to linguistic plurality? Is it possible to reconcile multilingualism with the goal of making communication in European Union law as certain as possible? This is predominantly a task for European legal linguists. ${ }^{26}$ The

24 See e.g., Busse (2007: 171); Fischer (2007: 162); Grzega (2006: 267).

25 See Christensen/Müller (2004: 10).

26 See Kjaer (2008: 150-151). 
European Reference Language Model answers these questions with a practical solution that is in accordance with the European Union law.

\subsection{Legal linguistic approach}

In contrast to the monolingual and multilingual models the European Reference Language Model is oriented along the lines of legal certainty and linguistic democracy. It aims at adequately representing all 23 official languages and making communication in the EU institutions and with the EU citizens legally certain and comprehensible. The two terms, and, in connection with these, linguistic divergence, have hitherto hardly been of any relevance in the academic debate on the EU linguistic regime (see above sections 6 and 7). From a linguistic point of view this is surprising, as they form the pivot of the functioning of legal communication in European Union law. Linguistic democracy is important, because democracy contains a model in itself that allows for the possibility of different identities on the level of communicative ethics, instead of enforcing and implementing homogenization as the main guideline. ${ }^{27}$ Such a concept is based on the assumption that language use in the EU institutions is always dialogically oriented. Dialogic legal action is dependent on different languages and language users. ${ }^{28}$ Legal certainty is significant, because the European Union is obliged to express itself to its citizens in a way that is comprehensible and, in particular, reliable. ${ }^{29}$ They have to be able to understand unequivocally what their rights and obligations are.

In its decisions, the Court of Justice of the European Union has repeatedly referred to transparency and legality. For openness enables EU citizens to participate more closely in the decisionmaking process and contributes to strengthening the principles of democracy and respect for fundamental rights. ${ }^{30}$ The principle of legality, a corollary to the principle of legal certainty, requires that European Union legislation be clear and foreseeable for those who are subject to it. Certainty and foreseeability must be observed all the more strictly in the case of provisions liable to entail financial consequences or laying down fines. ${ }^{31}$ From this perspective, the European Reference Language Model is the only language model that is based on legal linguistics and which underlines the close connection between language and law: Fundamental elements are the comparison of legal language established by the Court of Justice of the European Union (see above section 5.2), mother tongue communication and the principle of subsidiarity (see below section 8.3).

\subsection{Method}

How is the democratic fundamental right to language to be brought into conjunction with effective and certain communication? The European Reference Language Model suggests formulating European legal documents in two reference languages which are the so called common language (see above section 8.1). Factually, the model is about expressing European Union law not in one language, but in several. The law is to be re-considered within the idea of official languages in dialogue, which is an integrated part of cultures in dialogue; the other part are the different legal systems. The basis for a uniform legal order in legislation and the application of the EU law is constituted by two reference languages, which must be carefully compared linguistically and legally. This is demanded and made possible right from the start by the translation, which is methodologically the means for European communication: "The language of Europe is translation" 32 ,

27 Ehlich (2002: 53).

28 See Weigand (2008: 236).

29 See Joint Practical Guide. Guide of the European Parliament, the Council and the Commission for persons involved in the drafting of legislation within the Community institutions, accessible under http://eur-lex.europa.eu/en/techleg/ index.htm (23.1.2011).

30 ECJ, decision of 12.9.2007, ECR 2007, margin no. 3 - Association de la presse internationale ASBL.

31 ECJ, decision of 27.9.2006, ECR 2006, margin no. 42 and 43 - Jungbunzlauer AG.

32 See http://ec.europa.eu/rapid/pressReleasesAction.do? reference $=I P / 08 / 1631 \&$ format $=(23.1 .2011)$. 
says the Italian writer Umberto Eco. However, "the devil is in the translation," is a warning rightly issued by Henning Koch (2008: 46). It constitutes one of the weakest links. This calls for special care and diligence. A legal act must be phrased together with linguists, legal experts and the translation service in both reference languages in order to guarantee comprehensibility and legal certainty of laws and judgments and, consequently, the principle of linguistic democracy (see above section 8.2). The reference languages thus stand out from amongst the other EU languages.

Legal and linguistic questions have to be solved in a legal language comparison between these two reference languages which are considered to be equally authentic. They are reliable as sound common legal languages for the European Union expressing uniform meaning that has been established by legal language comparison (see above section 5.2). But they do not render the existing official languages obsolete; far from it! Bilinguality as a reference point is to be extended to all other EU languages, which are often at the same time national or native languages. The EU Member States themselves are responsible for this extension by translating the EU documents into their own official language for their citizens. It is already common practice that governments can apply for additional translation and have to take responsibility for this themselves. The EU linguistic regime, based on the principle of equal authenticity reflects the concept of the mother tongue. ${ }^{33}$ As a rule, this leads to the treaty languages or the official languages (Article 55 TEU, ex-Article 53 TEU and Article 24 paragraph 4 TFEU, ex-Article 21 TEC).

Closeness to citizens is a fundamental pillar of legal communication in the European Union. Decision-making must be brought as close to the citizens as possible within the Community, according to the principle of subsidiarity (Article 5 TEU, ex-Article 5 TEC). It therefore involves - wherever possible - the distribution of power between several levels of authority. The Community is not to seize any competences which can just as well be fulfilled by the EU Member States. However, clear dividing lines for applying the principle of subsidiarity are lacking. This lack opens up the field for different interpretations of this principle. In this respect the dialogic system of reference languages and mother tongue is best described as a subsidiary system: Translation into the mother tongue is only allowed from the reference languages. The authenticity of the translation thus results from the agreement with these languages. At least one reference language always functions as a yardstick. The reference languages may check each other reciprocally at the supranational level, the reference and native languages in relation to the EU Member States.

The European Reference Language Model deals explicitly with the situation of the Court of Justice of the European Union, which emphasizes the importance of the mother tongue for interaction between EU institutions and citizens. The Court uses an invariable working language and a varying language of the case, without, however, bringing them into any kind of relation with each other. For facilitating internal communication (during consultation), it actually even takes recourse to monolingualism. The working language, French, is not due to a majority decision. The reasons are to be found in the linguistic environment in francophone Brussels, Luxembourg and Strasbourg, as well as in the tradition of French being the language of diplomacy and administration (see above section 5.1). The plaintiff may decide freely on the language of the case, which must then be adhered to during the complete proceedings and in which the decision - quite by chance! - is pronounced with exclusive legally binding force. In this way, language choice becomes the pivot for the effect and the development of EU law and for legal certainty. The decision has to be translated into the other official languages. However, this does not automatically give the different language versions equal authority. This is where the European Reference Language Model proceeds from.

\subsection{Reference languages}

The reference languages together with the other official languages within the European Reference Language Model are able to create an adequate balance between linguistic plurality of the

33 See K. Luttermann (2009: 326-329). 
European Union - a richness which needs to be made use of - and efficiency in favour of comprehensibility and legal certainty. Which EU languages are to be reference languages? The model determines them according to the democratic majority principle. The Court of Justice of the European Union also takes the approach of limiting official languages to those which are most widely known in the European Union as "appropriate and proportionate (...) and in any event justified by the operating needs of the Office". ${ }^{34}$ These reference languages in dialogue are German and English. ${ }^{35}$ They have the highest proportion of mother tongue and foreign language speakers. German is spoken as a native language by 18 percent of EU citizens, and 38 percent have some knowledge of English as a foreign language. ${ }^{36}$ These two languages also represent the origins of the great European legal orders: the rule-based and the case-based system of regulation. German is the continental language and expresses civil-law thinking, whereas English is the common-law language. In the final instance, they have to converge in a joint system of regulation due to the unification of European Union law.

The European Reference Language Model reveals the following: Interdisciplinary competence is needed for solving questions of text production (e.g., terminology, structures of a text, text-type) under the conditions of multilingualism between comparative law, comparative legal linguistics and the science of translation. In the co-editing of the authentic texts, linguists, legal experts and translators are obliged to master not only two reference languages and two legal systems (Roman and Common law), but also to legally adjust translations for the national domain. This is necessary to preclude linguistic divergence in legal documents from the outset - before 'the horse has bolted' - and to guarantee legal certainty. At the moment, this has no stable basis (see above section 6). A flawed text version in even one EU language creates legal uncertainty in all EU Member States, because in every state all language versions are equally authentic. In the interest of EU citizens and the European Union as a whole, the quality of communication should take highest priority.

\section{Conclusions}

The European Reference Language Model shows a sustainable approach of promoting legal certainty and comprehensible communication with the reference and native languages, while at the same time maintaining the linguistically mediated respect of each EU Member State. The basic element of multilingualism remains in force. Every official language stays integrated in the EU linguistic regime and is held in esteem. In the academic debate on European legal integration, the model has already attracted some attention in the fields of linguistics and jurisprudence. ${ }^{37}$ The legal expert Isabel Schübel-Pfister (2007: 169), for example, suggests taking the model into consideration, because it may possibly take better account of the rightful trust of the EU citizens in their own language version than practice hitherto has done. For the judge Christian Lohse (2004: 106), the double-check of languages and legal orders creates trust, and is therefore advantageous. He remarks that the comparison of more than twenty language versions, on the other hand, will remain a theoretical demand, and this means permanent legal uncertainty for the citizens. The linguist Jan Engberg (2009: 190) appreciates the fact that the legal-linguistic approach solves the practical difficulty arising from maintaining the 23 official languages, without forfeiting the advantages of the multilingualism in the interpretation of the law. The future will show which road the European Union will finally take for determining the languages to be used in legal communication.

34 ECJ, decision of 9.9.2003, ECR 2003, margin no. 94 and 96 - Christina Kik.

35 An extension of the number of reference languages is conceivable. The method of reference may be extended - albeit to the detriment of efficiency - by giving more than two languages the status of reference language; see $\mathrm{C}$. and $\mathrm{K}$. Luttermann (2004: 1009).

36 See Special Eurobarometer: Europeans and their Languages of February 2006, p. 4, accessible under http:// ec.europa.eu/public_opinion/archives/ebs/ebs_243_sum_en.pdf (23.1.2011).

37 In support e.g., the linguist Ehlich (2009: 27 ) and the former president of the Bundesverfassungsgericht (German Federal Constitutional Court) Limbach (2008: 86). 


$\begin{array}{ll}\begin{array}{l}\text { Abbreviations } \\ \text { Council } \\ \text { Council Regulation }\end{array} & \begin{array}{l}\text { Council of the European Union } \\ \text { Council Regulation No 1 determining the languages to be used by } \\ \text { the European Economic Community }\end{array} \\ \text { EC } & \text { European Commission } \\ \text { ECA } & \text { European Court of Auditors } \\ \text { ECJ } & \text { Court of Justice of the European Union } \\ \text { ECR } & \text { European Court reports } \\ \text { EP } & \text { European Parliament } \\ \text { EU } & \text { European Union } \\ \text { TEC } & \text { Treaty establishing the European Community } \\ \text { TEU } & \text { Treaty on European Union } \\ \text { TFEU } & \text { Treaty on the Functioning of the European Union }\end{array}$

\section{Bibliography}

Ammon, Ulrich 2006: Language Conflicts in the European Union. In International Journal of Applied Linguistics 3, 319-338.

Ammon, Ulrich 2001: Verkehrssprachen in Europa - außer Englisch. Tübingen: Max Niemeyer.

Baumann, Max 1999: Europäische Sprachenvielfalt und das Recht oder der Vormarsch des Englischen und der Bilder. In Forstmoser, Peter/van der Crone, Hans Caspar/Weber, Rolf/Zobl, Dieter (eds.), Der Einfluss des europäischen Rechts auf die Schweiz. Zürich: Schulthess Polygraphischer Verlag, 15-26.

Berteloot, Pascale 2004: Die Europäische Union und ihre mehrsprachigen Rechtstexte. In Müller, Friedrich/Burr, Isolde (eds.), Rechtssprache Europas. Berlin: Duncker \& Humblot, 179-193.

Burr, Isolde/Gallas, Tito 2004: Zur Textproduktion im Gemeinschaftsrecht. In Müller, Friedrich/Burr, Isolde (eds.), Rechtssprache Europas. Berlin: Duncker \& Humblot, 195-242.

Busse, Ulrich 2007: Englisch als Lingua franca. In Muttersprache 2, 154-173.

Chaudenson, Robert (ed.) 2001: L'Europe parlera-t-elle anglais demain? Paris: L'Harmattan.

Christensen, Ralph/Müller, Friedrich 2004: Mehrsprachigkeit oder das eine Recht in vielen Sprachen. In Müller, Friedrich/Burr, Isolde (eds.), Rechtssprache Europas. Berlin: Duncker \& Humblot, 9-21.

Christensen, Ralph/Sokolowski, Michael 2004: Juristisches Entscheiden unter der Vorgabe von Mehrsprachigkeit. In Müller, Friedrich/Burr, Isolde (eds.), Rechtssprache Europas. Berlin: Duncker \& Humblot, 113-137.

Clyne, Michael 1995: The German Language in a Changing Europe. Cambridge: CUP.

Ehlich, Konrad 2009: Modalitäten der Mehrsprachigkeit. In Zeitschrift für Angewandte Linguistik 50, 7-31.

Ehlich, Konrad 2002: Europa der Sprachen. In Ehlich, Konrad/Schubert, Venanz (eds.), Sprachen und Sprachenpolitik in Europa. Tübingen: Stauffenburg, 33-57.

Ehlich, Konrad/Redder, Angelika 2008: Mehrsprachigkeit und Europa. In Osnabrücker Beiträge zur Sprachtheorie 74, 5-19.

Engberg, Jan 2009: Durchschaubarkeit durch Vielfalt. In Muttersprache 3, 181-191.

Fischer, Roswitha 2007: Englisch als Lingua franca in Europa. In Fischer, Roswitha (ed.), Herausforderungen der Sprachenvielfalt in der Europäischen Union. Baden-Baden: Nomos, 149-162.

Gahler, Michael 2007: Erfahrungen mit der Sprachenvielfalt im Europäischen Parlament. In Fischer, Roswitha (ed.), Herausforderungen der Sprachenvielfalt in der Europäischen Union. Baden-Baden: Nomos, 60-65.

Grzega, Joachim 2006: EuroLinguistischer Parcours. Frankfurt am Main: IKO.

Kelz, Heinrich 2002: Einführung: Europäische Mehrsprachigkeit. In Kelz, Heinrich (ed.), Die sprachliche Zukunft Europas. Baden-Baden: Nomos 7-15.

Kirchhof, Paul 2002: Nationalsprachen und Demokratie in Europa. In Ehlich, Konrad/Schubert, Venanz (eds.), Sprachen und Sprachenpolitik in Europa. Tübingen: Stauffenburg, 205-220.

Kjaer, Anne Lise 2008: Introduction: Language as Barrier and Carrier of European Legal Integration. In Petersen, Hanne/Kjaer, Anne Lise/Krunke, Helle/Madsen, Mikael Rask (eds.), Paradoxes of European Legal Integration. Aldershot: Ashgate, 149-156. 
Koch, Henning 2008: A Legal Mission. In Petersen, Hanne/Kjaer, Anne Lise/Krunke, Helle/Madsen, Mikael Rask (eds.), Paradoxes of European Legal Integration. Aldershot: Ashgate, 45-63.

Levits, Egils 2007: Probleme der Sprachenvielfalt am Europäischen Gerichtshof. In Fischer, Roswitha (ed.), Herausforderungen der Sprachenvielfalt in der Europäischen Union. Baden-Baden: Nomos, 44-50.

Limbach, Jutta 2008: Hat Deutsch eine Zukunft? München: C.H. Beck.

Lohse, W. Christian 2004: Sprache und Recht in der EU. In Lohse, Christian W./Arnold, Rainer/Greule, Albrecht (eds.), Die deutsche Sprache in der Europäischen Union. Baden-Baden: Nomos, 96-108.

Lölke, Dirk 2007: Die Handhabung der Sprachenvielfalt im Bereich des Rates der Europäischen Union. In Fischer, Roswitha (ed.), Herausforderungen der Sprachenvielfalt in der Europäischen Union. Baden-Baden: Nomos, 66-71.

Luttermann, Claus 1999: Rechtssprachenvergleich in der Europäischen Union. In Europäische Zeitschrift für Wirtschaftsrecht 13, 401-404.

Luttermann, Claus/Luttermann, Karin 2004: Ein Sprachenrecht für die Europäische Union. In Juristenzeitung 20, 1002-1010.

Luttermann, Karin 2009: Multilingualism in the European Union. In Grewendorf, Günther/Rathert, Monika (eds.), Formal Linguistics and Law. Berlin: Mouton de Gruyter 315-338.

Luttermann, Karin 2008: Demokratiegebot. In Eichhoff-Cyrus, Karin M./Antos, Gerd (eds.), Verständlichkeit als Bürgerrecht? Mannheim: Dudenverlag, 211-229.

Luttermann, Karin 2007: Mehrsprachigkeit am Europäischen Gerichtshof. In Heller, Dorothee/Ehlich, Konrad (eds.), Studien zur Rechtskommunikation. Bern: Peter Lang, 47-80.

Mattila, Heikki 2008: European Integration and Legal Communication. In Petersen, Hanne/Kjaer, Anne Lise/Krunke, Helle/Madsen, Mikael Rask (eds.), Paradoxes of European Legal Integration. Aldershot: Ashgate, 253-276.

Šarčević, Susan 1997: New Approach to Legal Translation. The Hague: Kluwer.

Schubarth, Martin 2001: Die Bedeutung der Mehrsprachigkeit der schweizerischen Gesetze für die höchstrichterliche Rechtsprechung. In LeGes 3, 49-57.

Schübel-Pfister, Isabel 2007: Chancen und Risiken einer multilingualen Rechtsgemeinschaft. In Fischer, Roswitha (ed.), Herausforderungen der Sprachenvielfalt in der Europäischen Union. Baden-Baden: Nomos, 165-172.

Schübel-Pfister, Isabel 2004: Sprache und Gemeinschaftsrecht. Berlin: Duncker \& Humblot.

Sturm, Fritz 2002: Lingua Latina fundamentum et salus Europae. In The European Legal Forum 6, 313-320.

Van Els, Theo 2006: Multilingualismus in der Europäischen Union. In Wolff, Dieter (ed.), Mehrsprachige Individuen vielsprachige Gesellschaften. Frankfurt am Main: Peter Lang, 11-30.

Weigand, Edda 2008: Towards a Common European Thinking. In Petersen, Hanne/Kjaer, Anne Lise/Krunke, Helle/ Madsen, Mikael Rask (eds.), Paradoxes of European Legal Integration. Aldershot: Ashgate, 235-252.

Wimmer, Rainer 2009: Zur Verflechtung von Spracharbeit und Rechtsarbeit in der EU. In Muttersprache 3, 234-239.

Wu, Huiping 2005: Das Sprachenregime der Institutionen der Europäischen Union zwischen Grundsatz und Effizienz. Frankfurt am Main: Peter Lang. 